\author{
Andrea Farkas, Josko Parunov \\ E-mail: jparunov@fsb.hr \\ University of Zagreb, Faculty of Mechanical Engineering and Naval Architecture \\ Ivana Lučića 5, 10002 Zagreb, Croatia \\ Marko Katalinić \\ University of Split, Faculty of Maritime Studies \\ Ruđera Boškovića 37, 21000 Split, Croatia
}

\title{
Wave Statistics for the Middle Adriatic Sea
}

\begin{abstract}
Summary
The paper presents the methodology and results of the sea state statistics development for the middle Adriatic Sea. The study is based on the World Waves Atlas containing data of sea states in the Adriatic Sea calibrated using different satellite missions and numerical wave model simulations during the period of past 23 years. Wave scatter diagram and wave rose at the location in the middle Adriatic Sea are derived from the data. The 3-parametric Weibull distribution and the log-normal distribution for significant wave height and peak spectral periods respectively, are fitted through the data in the World Waves Atlas. Based on available data, the relation between wind speed and wave height is established by regression analysis. Comparison of the relationship between the significant wave height and peak spectral period is performed between the data from the World Waves Atlas and the Tabain's wave spectrum, frequently used for sea states in the Adriatic Sea. Finally, the most probable extreme sea states for different return periods are calculated and results are compared with another relevant study for the long-term prediction of sea states in the Adriatic Sea.
\end{abstract}

Key words: The Adriatic Sea, wave statistics, satellite measurements

\section{Introduction}

The aim of the present study is to develop the sea states statistics for the central region of the Adriatic Sea. The Adriatic represents an important resource for the surrounding countries. While aiming at achieving quality, safe and sustainable exploitation in all economic sectors that are dependent on this resource, it is necessary to have deep understanding of its local wave climate. Possessing knowledge about possible sea states, its averages and extremes for a certain area, is essential for activities in relevant maritime sectors such as shipbuilding, maritime transport, aquaculture and fisheries, nautical tourism and potentially even renewable wave energy harvesting [1]. 
High quality sea state statistics can serve as a design basis for ships to be built for local use (e.g. coastal cruisers, ferries, workboats, patrol vessels and pleasure crafts etc.). Furthermore, it can aid the decision-making process when acquiring existing vessels in terms of operability estimates. All stationary objects on sea (from near-shore mariculture sites to offshore platform installations) depend greatly on well evaluated extreme conditions they can encounter during their service life as well as on the longterm cumulative wave loading they are exposed to. Finally, safety of maritime transport is a key issue for the Adriatic Sea because of its semi-enclosed character and a large number of merchant ships passing toward its northern ports carrying goods toward the central Europe and posing potential risk of pollution in case of accident. Reliable wave statistics are a necessary prerequisite in the performance of realistic analysis of structural failure in such a case. Structural failure may occur due to ship collision, grounding or some other type of human mistake. Probability of such an accident is unavoidably increasing with number of ships involved in transport [2]. From an engineering point of view in case of such an accident, the ship strength could be considerably reduced making wave loads important for the structural safety assessment.

Probabilistic description of the marine environment is also being used for the seakeeping performance, i.e. safety and comfort assessment of RO-RO ships, ferries and small ships. For example, the Directive 2003/25/EC of the European Parliament and of the Council of 14 April 2003 on specific stability requirements for RO-RO passenger ships requires refined and reliable probabilistic description of sea states in coastal seas in order to decide if retrofitting of an existing ship would be required. Since retrofitting is generally quite expensive, it is very useful to develop a histogram of sea states for both safety and economic reasons [2].

The motivation for the study is that previously available systematic data about waves in the Adriatic Sea is mainly based on the Atlas of Climatology of the Adriatic $\mathrm{Sea}$ [3] and data measured in-situ by buoys that were periodically available near the west (Italian) Adriatic coast [4]. Atlas of Climatology of the Adriatic Sea [3] is a document provided by the Republic of Croatia Hydrographic Institute. The data collected are visual observations made from ships making them suitable for application in the analysis of seagoing vessels but are also limited in terms of accuracy and by the fact that extremes were avoided by ships and disregarded when the data were processed. The observations were made and the data published several decades ago. Several wave measuring buoys that were recording and reporting wave motion for longer time periods were mostly located along the Adriatic west coast e.g. [4].

Wave spectrum is a necessary prerequisite for spectral analysis of marine structures. The wave spectrum so far commonly used in the Adriatic Sea is the single parametric Tabain's wave spectrum. The Tabain's spectrum is obtained by modification of the JONSWAP spectrum based on a limited number of measured spectra [5].

There are two wave atlases available for the Adriatic Sea, the MedAtlas [6] and the World Waves Atlas (WWA) [7]. The MedAtlas is an extensive atlas of wind and wave conditions based on the information derived from the archive of the European Centre 
for Medium-Range Weather Forecasts, UK and calibrated on the basis of data available from the ERS1-2 and Topex satellites, which is a result of a project sponsored by the Italian, French and Greek Navies. The World Waves database contains data calibrated using different satellite missions and numerical wave model simulations. A grid with about 40 calibration points is available for the Adriatic Sea within World Waves [8].

In the present study, the sea states statistics is generated using data originating from the WWA. The wave statistics is analysed for one location near the island of Palagruža with the latitude-longitude coordinates: $42.5^{\circ}$ North $-16.5^{\circ}$ East. This location has been selected because of an elevated risk of ship collision in the region [9]. The first part of the paper provides a general description of the data used for the statistical analysis. The following section provides a wave scatter diagram for the middle Adriatic derived from the available database. Then, the joint probability distribution of significant wave heights and peak spectral periods is derived using Weibull 3-parametric and log-normal distributions for significant wave heights and peak periods respectively. The available data enabled the relation between the wind speed and wave height to be established that can be useful in predicting sea states based on the wind speed forecast. In addition, the relationship of significant wave height and peak period is compared between the measured data and those embedded in the Tabain's spectrum. Finally, extreme sea states are calculated for different return periods and compared with other published results. The paper ends with an appropriate conclusions and recommendations for future studies.

\section{World Waves Atlas (WWA)}

The WWA is the common name for a series of comprehensive high resolution interactive wind and wave atlases [7]. The WWA contains satellite altimeter data from the following missions: Geosat (1986 -1989), TOPEX (1992 - 2002), Topex/Poseidon (September 2002 - 2005), Jason (January 2002-2008), EnviSat (October 2002 - October 2010), Geosat Follow-On (January 2000 - 2008), Jason-2 (July 2008 - ongoing), Jason-1s (February 2009 - March 2012). Significant wave heights and wind speeds are measured at specific points each time the satellite passes. Validations of the satellite data have been made through extensive comparisons against the buoy data from around the world. The repeat cycle of satellites falls within the order of 10-35 days, and thus the data set does not represent a high temporal resolution of measurements. Likewise, altimeter offers only significant wave height and wind speed data. In order to provide high resolution directional wave information, these high precision satellite data are combined with the best available numerical model data, calibrated against the long-term satellite data. The offshore grid points for which data are available in the Adriatic Sea are shown in Figure 1 [8]. 


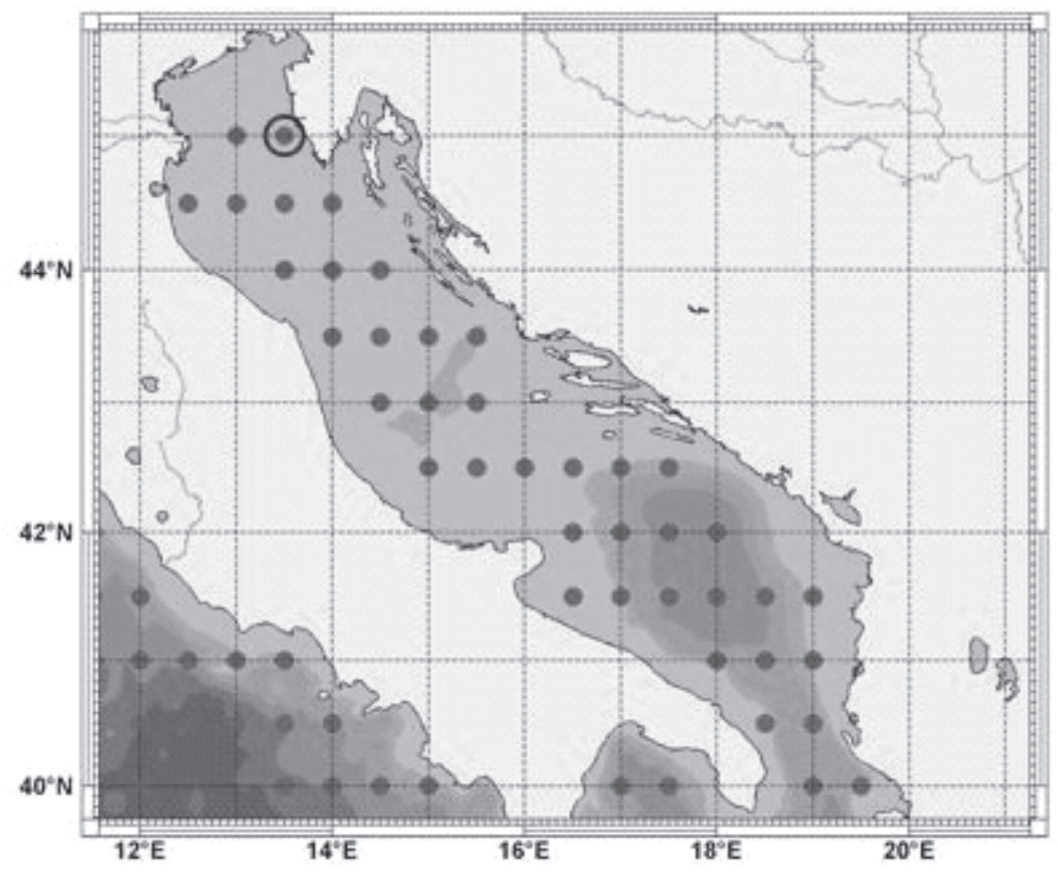

Figure 1 Offshore grid points under World Waves in the study area [8]

Available data parameters are listed in Table 1. All parameters are available in 6-hour intervals. The local wind conditions are utilised by the spectral partition to identify the wind sea component, and the remaining energy is assigned to the swell parameter [8].

Table 1 Available parameter data [8]

\begin{tabular}{|c|c|}
\hline NAME & DESCRIPTION \\
\hline year & Year of observation \\
\hline $\mathrm{mm}$ & Month of observation \\
\hline $\mathrm{dd}$ & Day of observation \\
\hline hh & Hour of observation \\
\hline SWH & Significant wave height Hs (Sea and Swell) \\
\hline PP1D & Peak period of 1d spectra \\
\hline MWP & Mean wave period T-10 (Sea and Swell) \\
\hline SHWW & Significant wave height Hs (Sea) \\
\hline MPWW & Mean wave period T-10 (Sea) \\
\hline SHPS & Significant wave height Hs (Swell) \\
\hline
\end{tabular}




\begin{tabular}{|c|c|}
\hline MPPS & Mean wave period T-10 (Swell) \\
\hline fro & Mean wave direction $\vartheta($ Sea and Swell) \\
\hline frw & Mean wave direction $\vartheta($ Sea) \\
\hline frs & Mean wave direction $\vartheta($ Swell) \\
\hline WD & Wind direction Wdir \\
\hline WS & Wind speed Wsp \\
\hline
\end{tabular}

\section{Statistical results}

The extensive data set recorded since September 1992 until the end of January 2016 allows for a variety of analyses, depending on the specific purpose of the research. In the present paper, a basic statistical analysis is performed. Table 2 represents a wave scatter diagram for a case study location situated near the Croatian island of Palagruža, in the central part of the Adriatic Sea, with latitude-longitude coordinates: $42.5^{\circ}$ North, $16.5^{\circ}$ East. Table 2 combines the significant wave height $(H s)$ and peak spectral wave period $(T p)$. Each "bin" in the table represents the upper limit of that specific class (e.g. $H s$ of $1.5 \mathrm{~m}$ represents significant wave height between 1 and $1.5 \mathrm{~m}$ ).

Table 2 Wave scatter diagram for latitude-longitude coordinates: $42.5^{\circ}$ North, $16.5^{\circ}$ East

\begin{tabular}{|c|c|c|c|c|c|c|c|c|c|c|c|c|c|c|}
\hline $\mathbf{T}_{\mathrm{p}} / \mathbf{H}_{\mathbf{S}}$ & $\mathbf{0 . 5}$ & $\mathbf{1}$ & $\mathbf{1 . 5}$ & $\mathbf{2}$ & $\mathbf{2 . 5}$ & $\mathbf{3}$ & $\mathbf{3 . 5}$ & $\mathbf{4}$ & $\mathbf{4 . 5}$ & $\mathbf{5}$ & $\mathbf{5 . 5}$ & $\mathbf{6}$ & $\mathbf{6 . 5}$ & Sum \\
\hline $\mathbf{1}$ & 0 & 0 & 0 & 0 & 0 & 0 & 0 & 0 & 0 & 0 & 0 & 0 & 0 & 0 \\
\hline $\mathbf{2}$ & 0 & 0 & 0 & 0 & 0 & 0 & 0 & 0 & 0 & 0 & 0 & 0 & 0 & 0 \\
\hline $\mathbf{3}$ & 4934 & 1666 & 14 & 0 & 0 & 0 & 0 & 0 & 0 & 0 & 0 & 0 & 0 & 6614 \\
\hline $\mathbf{4}$ & 3552 & 6815 & 861 & 20 & 0 & 0 & 0 & 0 & 0 & 0 & 0 & 0 & 0 & 11248 \\
\hline $\mathbf{5}$ & 589 & 3800 & 2616 & 666 & 36 & 0 & 0 & 0 & 0 & 0 & 0 & 0 & 0 & 7707 \\
\hline $\mathbf{6}$ & 260 & 1114 & 1533 & 1256 & 500 & 113 & 5 & 0 & 0 & 0 & 0 & 0 & 0 & 4781 \\
\hline $\mathbf{7}$ & 166 & 326 & 459 & 445 & 393 & 255 & 70 & 14 & 3 & 0 & 0 & 0 & 0 & 2131 \\
\hline $\mathbf{8}$ & 93 & 103 & 138 & 159 & 128 & 111 & 91 & 51 & 21 & 7 & 1 & 0 & 0 & 903 \\
\hline $\mathbf{9}$ & 28 & 68 & 36 & 44 & 54 & 38 & 38 & 22 & 12 & 5 & 1 & 1 & 1 & 348 \\
\hline $\mathbf{1 0}$ & 11 & 29 & 14 & 10 & 13 & 11 & 10 & 7 & 2 & 1 & 4 & 1 & 0 & 113 \\
\hline $\mathbf{1 1}$ & 4 & 8 & 4 & 2 & 0 & 1 & 0 & 0 & 0 & 0 & 0 & 0 & 0 & 19 \\
\hline $\mathbf{1 2}$ & 8 & 3 & 4 & 1 & 0 & 0 & 0 & 0 & 0 & 0 & 0 & 0 & 0 & 16 \\
\hline $\mathbf{1 3}$ & 14 & 0 & 1 & 0 & 0 & 0 & 0 & 0 & 0 & 0 & 0 & 0 & 0 & 15 \\
\hline $\mathbf{1 4}$ & 4 & 1 & 0 & 0 & 0 & 0 & 0 & 0 & 0 & 0 & 0 & 0 & 0 & 5 \\
\hline Sum & 9663 & 13933 & 5680 & 2603 & 1124 & 529 & 214 & 94 & 38 & 13 & 6 & 2 & 1 & 33900 \\
\hline
\end{tabular}

The wave scatter diagram shows expected concentration on low values and almost 70 percent of significant wave heights are lesser than one meter, which is consistent with the results obtained in [9], where 80 percent of the significant wave heights are 
lesser than 1.1 meter. The average significant wave height reads $0.87 \mathrm{~m}$, being also in a fair agreement with $0.8 \mathrm{~m}$ from [9]. The most likely sea state in the middle Adriatic is described by the significant wave height between 0.5 and $1 \mathrm{~m}$ and the peak period between 3 and 4s. The highest significant wave height of $H s=6.05$ was recorded on 8 December 1992 at 18 PM.

The wave rose, representing the percentage of direction from which waves are progressing, in addition to the percentage of significant wave heights, is shown in Figure 2. From Figure 2 one can conclude that the most dominant wind pattern at the analysed location is jugo (sirocco in Italian), blowing along the whole Adriatic Sea, predominantly from the south (S) and southeast (SE) quadrants, mainly with moderate and strong force. The second characteristic wind pattern in the Adriatic is bura (bora in Italian), the strong, gusty and cold wind which blows from the northeast (NE) quadrant. However, it may be seen from the wave rose that bura is not frequently present in this location and it is not producing high waves as often as SE winds. Another dominant wave pattern that can be observed are waves coming from the northwest quadrant (NW) that are caused by maestral wind, classified as a seasonal coastal circulation wind occurring frequently, especially during summer periods, creating low to moderate waves which have a long fetch to develop in this direction. Thus, its moderate waves also dominate the wave rose due to their high frequency of occurrence.

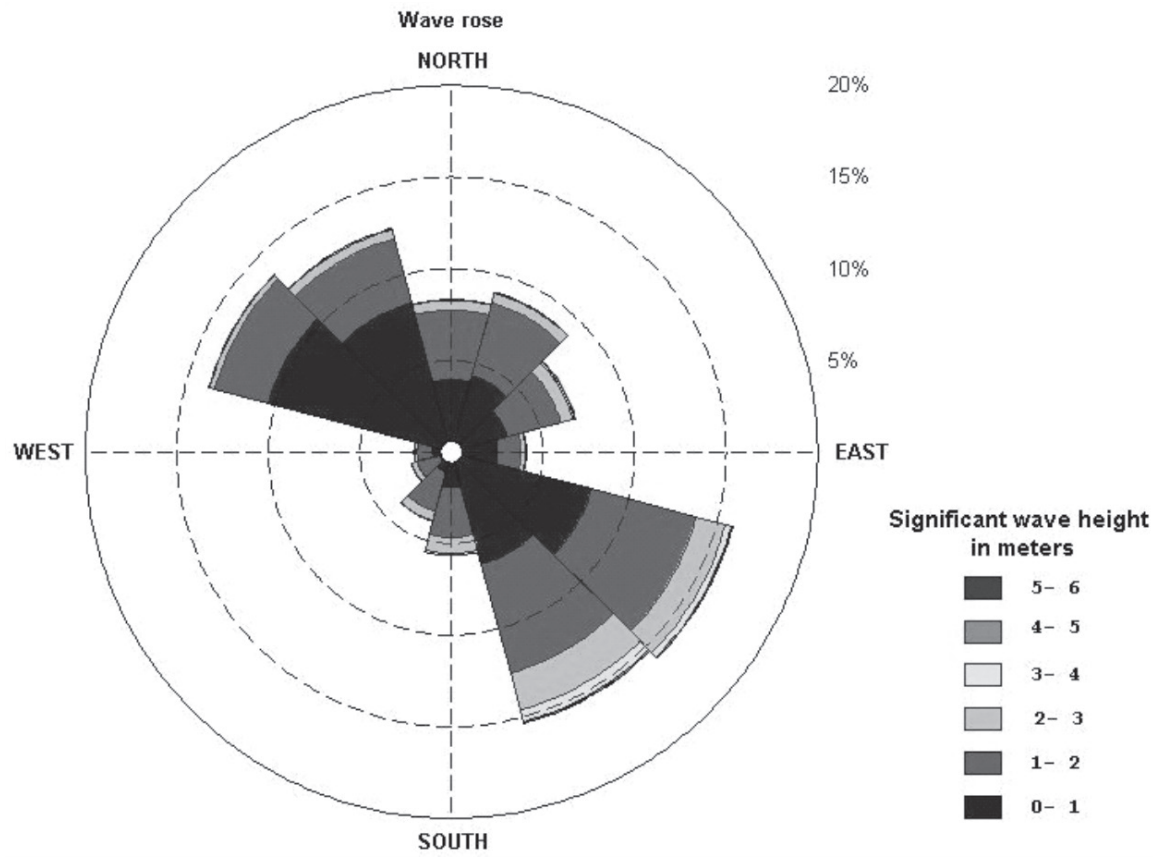

Figure 2 Wave rose for latitude-longitude coordinates: $42.5^{\circ}$ North, $16.5^{\circ}$ East 
The theoretical probability distribution is fitted to the observed data in order to get a smooth histogram of sea state occurrences and to be able to predict extreme sea states with a very low probability of exceeding, according to the procedure described in detail in [10]. Distribution usually used for the probabilistic description of sea states in long term periods is the 3-parameter Weibull distribution, which is given as:

$$
F\left(H_{S}\right)=P\left(\hat{H}_{S}<H_{S}\right)=1-e^{-\left(\frac{\hat{H}_{S}-\varepsilon}{\theta}\right)^{\alpha}}, \quad H_{S}, \hat{H}_{S} \geq \varepsilon
$$

where $\varepsilon$ is the location parameter, $\theta$ is the scale parameter and $\alpha$ the shape parameter. The probability of $H_{S}$ being exceeded is given as:

$$
Q\left(H_{S}\right)=1-P\left(H_{S}\right)
$$

For each value $H_{S, i}$ from the last row in Table 2, the empirical exceedance probability is given by the Weibull expression:

$$
Q\left(H_{S, i}\right)=\frac{\sum_{j=1}^{i} f_{j}}{N+1}
$$

The numerator in Equation (3) represents the cumulative frequency of all values larger than or equal to $H_{S, i}$, while $N$ represents the total number of observations ( $N=33900$ in the present case). Histograms of significant wave heights and empirical exceeding probability are presented in Figure 3.
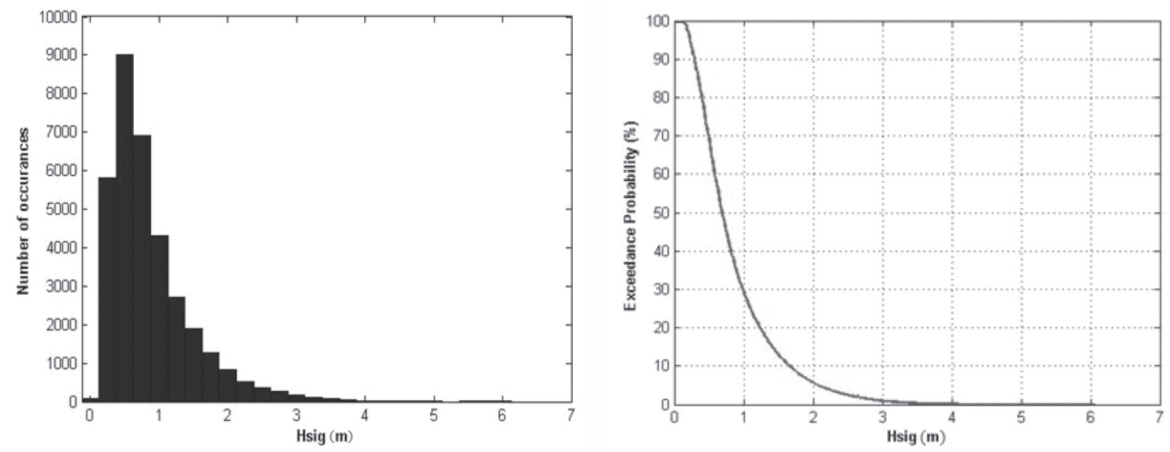

Figure 3 Histogram of significant wave heights (left) and empirical exceeding probability (right)

According to the procedure described in [10], Weibull parameters are determined and they read:

$$
\varepsilon=0.5565, \alpha=0.9996, \theta=0.5762 .
$$

Figure 4 represents the comparison of data from the WWA and theoretical cumulative probability distribution. 


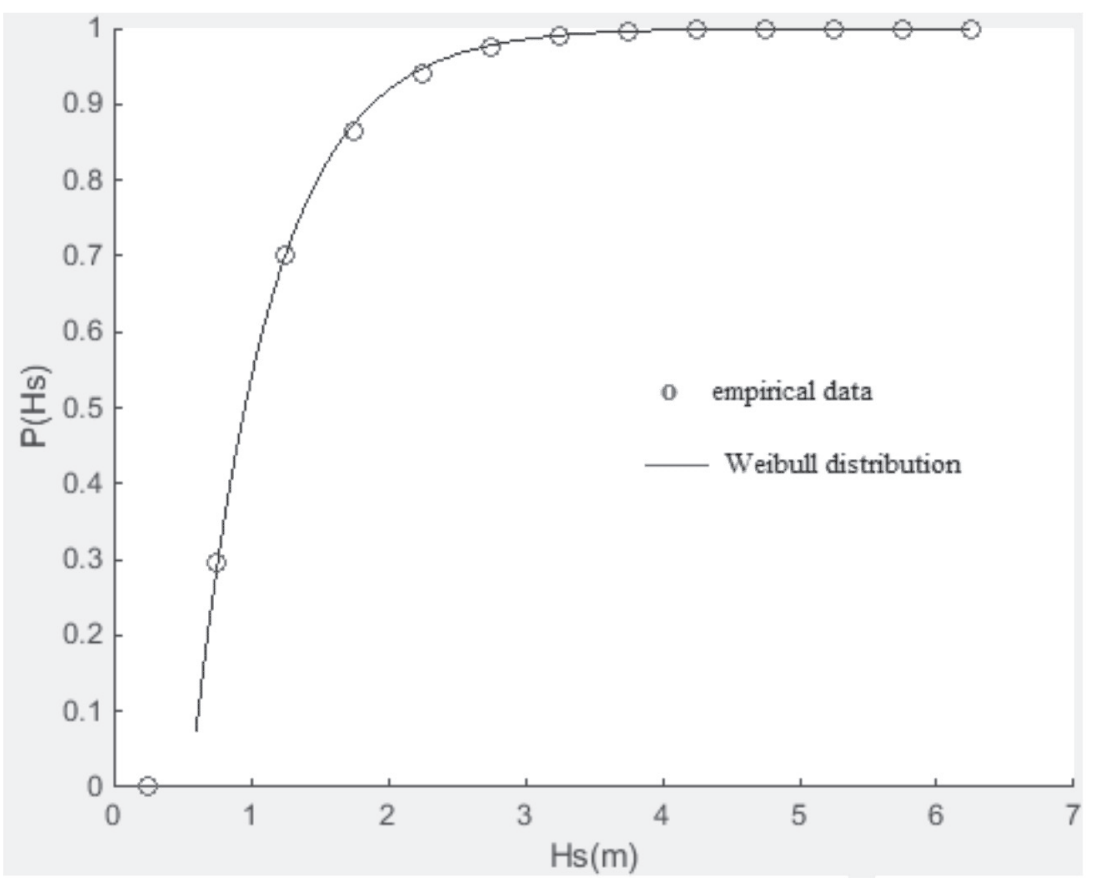

Figure 4 Comparison of measured and theoretical cumulative probability distribution

Conditional distribution of peak spectral period is also determined. For the conditional distribution of spectral peak period, log-normal distribution is used, according to the procedure shown in [11]:

$$
F\left(T_{p} / H_{S}\right)=\Phi\left(\frac{\ln T_{p}-\mu_{\ln T_{p}}}{\sigma_{\ln T_{p}}}\right)
$$

where $\Phi$ is the probability distribution function of a standard normal distribution, $\mu_{l n T p}$ is the mean value of logarithm values of the peak period and $\sigma_{l n T p}$ the standard deviation of logarithm values of the peak period. The mean value of logarithm values of the peak period and the standard deviation of logarithm values of the peak period can be calculated as:

$$
\begin{gathered}
\mu_{\ln T_{p}}=\ln \frac{\mu_{T_{p}}^{2}}{\sqrt{\sigma_{T_{p}}^{2}+\mu_{T_{p}}^{2}}} \\
\sigma_{\ln T_{p}}=\sqrt{\ln \left(1+\frac{\sigma_{T_{p}}^{2}}{\mu_{T_{p}}^{2}}\right)}
\end{gathered}
$$


where $\mu_{T p}$ is the mean value of the peak period and $\sigma_{T p}$ is the standard deviation of the peak period. Probability density function peak period for given significant wave height reads:

$$
f\left(T_{p} / H_{S}\right)=\frac{1}{T_{p} \sigma_{\ln T_{p}} \sqrt{2 \pi}} e^{-\frac{1}{2}\left(\frac{\ln T_{p}-\mu_{\ln T_{p}}}{\sigma_{\ln T_{p}}}\right)^{2}}
$$

Figure 5 shows the comparison between the empirical and theoretical frequency for significant wave height of $2.75 \mathrm{~m}$.

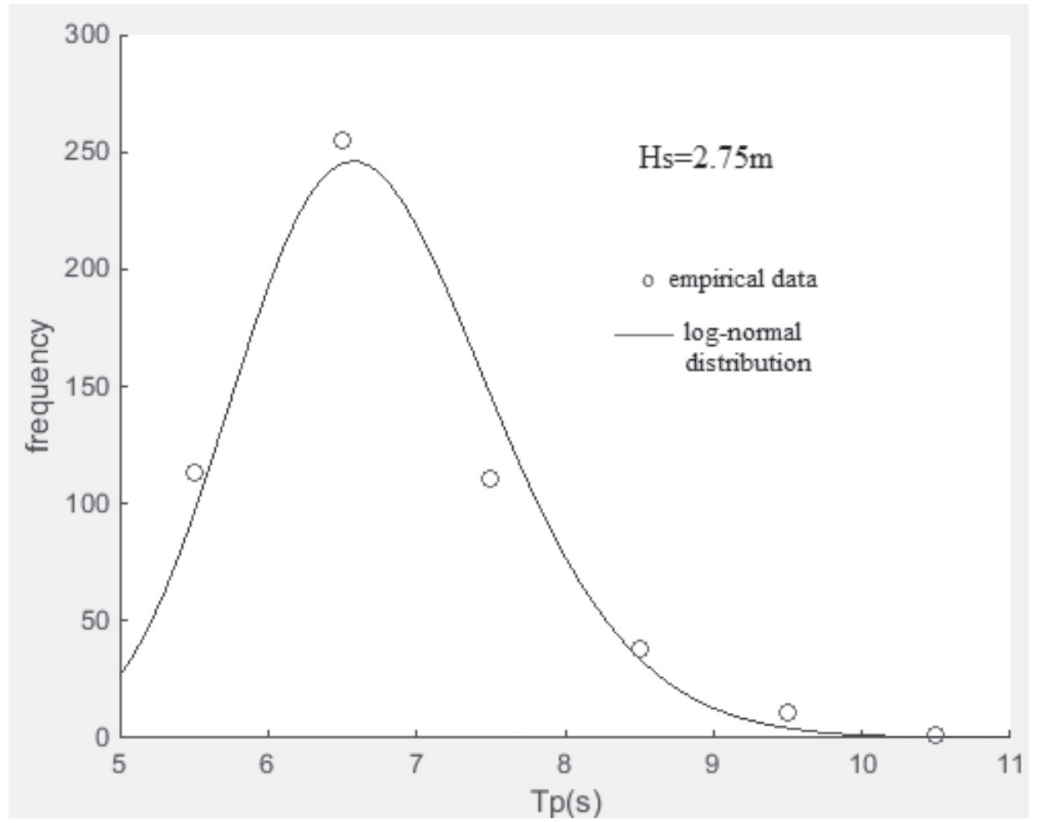

Figure 5 Comparison between empirical and theoretical frequency of peak periods

The relation between the significant wave height and the mean value of the peak period is defined by the following regression equation:

$$
\mu_{T_{Z}}=2.327 \ln \left(H_{S}\right)+4.481
$$

The regression equation (8) enables us to estimate peak wave periods for larger significant wave heights, where empirical data for such periods are missing.

\section{Dependence of significant wave height on wind speed}

The available parameter data give two significant wave height components. The first component is the significant height of wind waves and the second component is 
the significant height of the primary swell. The vector sum of these two components gives the total significant wave height [12]. Figure 6 shows the relation between the significant wave height of wind waves and the wind speed with a parabolic trend line derived. The parabolic trend line, obtained using MS Excel, was found to be best suited, especially for higher wind speeds. It should be noted that the regression curve was forced to pass through the origin of the coordinate system. The sum of squares of residuals (also called the coefficient of determination) $\left(R^{2}\right)$ is quite highly indicative of the parabolic relationship derived to be generally fairly reliable, but it should be used with care as it obviously overlooks the character and value of specific situations/points that are in some cases over- or underestimated in order of magnitude by several times.

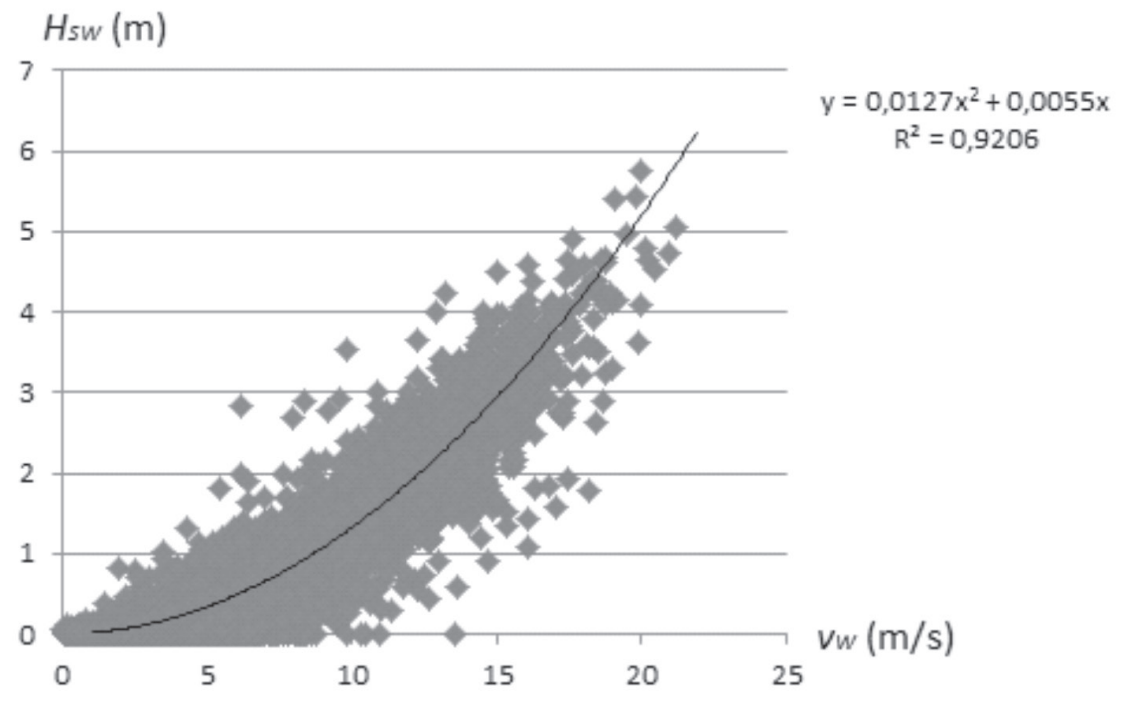

Figure 6 Relation between significant wind wave height and wind speed

\section{Dependence of spectral modal frequency on significant wave height}

For seakeeping analyses of ships and floating structures in the Adriatic Sea, the Tabain's spectrum has been used for a long time [5]. Details of the Tabain's wave spectra are already described in literature, e.g. [1][2][5] and they are not repeated here. The Tabain's spectrum is a one-parameter wave spectrum entirely described by the significant wave height $H_{S}$.

The relation between the modal frequency of the Tabain's wave spectrum [5] and the significant wave height is given as:

$$
\omega_{m}=0.32+\frac{1.8}{H_{S}+0.6}
$$


As the available data provide the peak period parameter, the modal frequency is calculated from the well-known expression:

$$
\omega_{m}=\frac{2 \pi}{T_{p}}
$$

It should be noted that the modal frequency represents the peak frequency of spectra [5]. Figure 7, obtained by a computer code in the MATLAB programming language, shows the comparison between the measured data and the Tabain's equation (8):

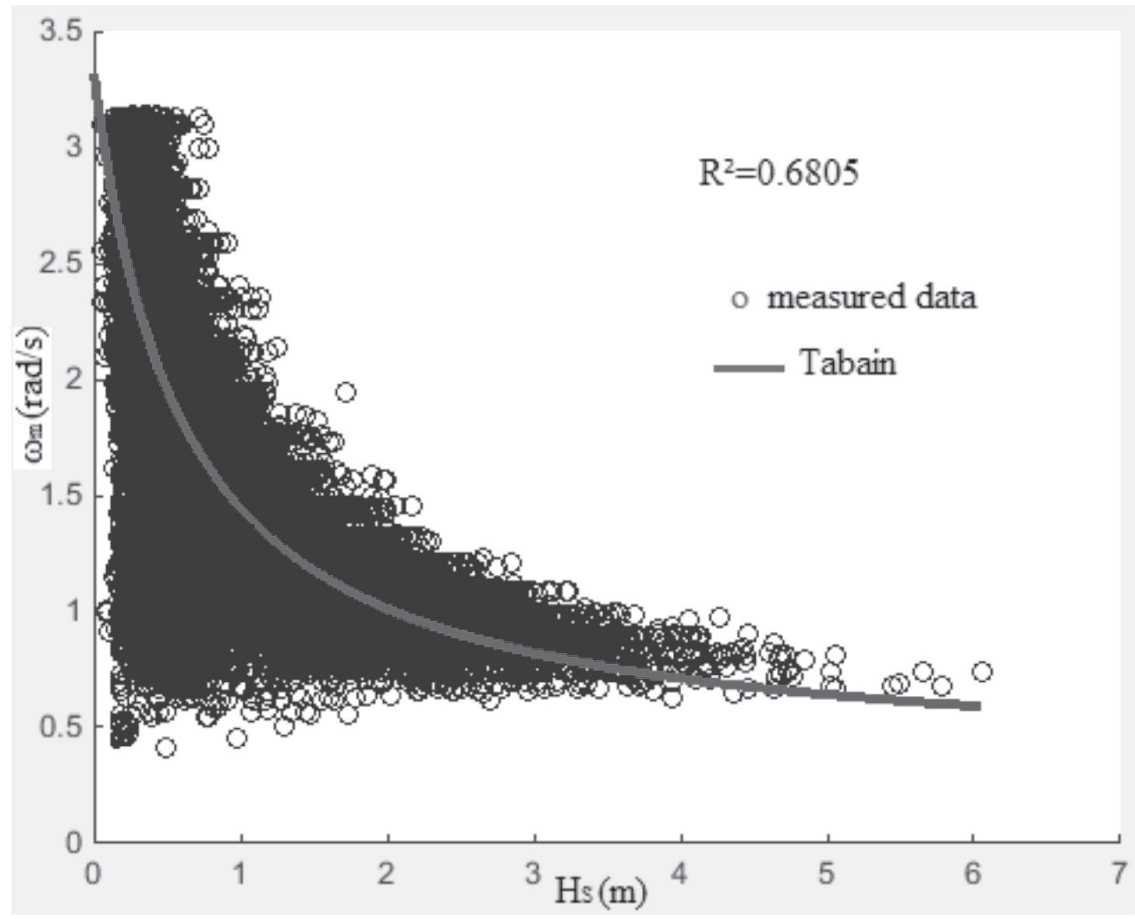

Figure 7 Experimental and theoretical relation between spectral modal frequency and significant wave height

As may be seen from Figure 7, the measured peak frequency for higher significant wave heights is higher than the one given by Equation (8). The same tendency may be seen in the original data for definition of the Tabain's spectrum [5]. Higher peak frequency than expected by the Tabain's spectrum corresponds to shorter waves. This pronounced wave steepness can be explained by specific characteristics of the Adriatic basin wave climate i.e., the occurrence of very strong winds on a limited fetch resulting in relatively high and short waves of "young" sea states compared to commonly "fully developed" waves observed in oceanic waters [1]. 
As the coefficient of determination is rather low $\left(R^{2}=0.68\right)$, it may be concluded that the single-parameter Tabain's wave spectrum is not sufficient to describe all relevant sea conditions occurring in the middle Adriatic Sea.

\section{Extreme sea states}

The most probable extreme sea states are calculated according to the procedure described in [10]. The probability of exceeding significant wave height can be calculated as:

$$
Q\left(H_{S}^{R P}\right)=r \frac{1}{R P}
$$

where $H_{S}{ }^{R P}$ is the significant wave height corresponding to the specific return period $R P, r$ is the interval between the elements of the sample (expressed in years) and $R P$ is the return period (expressed in years). The interval between the elements of the sample is 0.000685 years (6 hours). In Section 3 of the paper, the probability of exceeding is approximated by the 3-parameter Weibull distribution. Using this distribution, the most probable extreme wave heights for different return periods can be easily calculated using Equation (11):

$$
H_{S}^{E}=\theta\left(-\ln \left(Q\left(H_{S}^{R P}\right)\right)^{\frac{1}{\alpha}}+\varepsilon\right.
$$

where $\alpha, \theta$ and $\varepsilon$ are Weibull parameters (Section 3), $Q\left(H_{S}{ }^{R P}\right)$ is the probability of exceeding given by equation (10) and $H_{S}{ }^{E}$ is the most probable extreme significant wave height for the return period $R P$. Table 3 shows the most probable extreme significant wave heights calculated for return periods of $1,5,10,20,50$ and 100 years.

Table 3 The most probable extreme significant wave heights

\begin{tabular}{|c|c|}
\hline Return period (year) & $H_{S}{ }^{E}(\mathrm{~m})$ \\
\hline 1 & 4.76 \\
\hline 5 & 5.69 \\
\hline 10 & 6.09 \\
\hline 20 & 6.49 \\
\hline 50 & 7.02 \\
\hline 100 & 7.42 \\
\hline
\end{tabular}

There are no similar studies available from literature on wave statistics at this location to enable a comparison with the obtained results. There are reported measurements available in respect of the open part of the northern Adriatic [14], where extreme significant wave heights for different return periods are calculated. The method used by authors in that paper was the approximation of the distribution of monthly extremes by the Gumbel distribution. Monthly extremes were available for a period of 10 years 
(1978-1986 and 1992). The absolute maximum significant wave height measured in 10 years was $6.58 \mathrm{~m}$ measured in December 1979. The theoretical prediction of the most probable extreme significant wave height in 20 years reads $7.20 \mathrm{~m}$, while the most probable extreme significant wave height for a return period of 100 years reads $8.57 \mathrm{~m}$. These values are somewhat higher compared to those presented in Table 3 for the middle Adriatic. One possible reason for such discrepancies could be that sea states in the north Adriatic, as analysed in [14], are more severe because extreme values are reported during events of southeast (SE) storm winds, where these winds reach the longest fetch in the northern Adriatic.

\section{Conclusion}

The paper presents the probabilistic description of sea state occurrences in the middle part of the Adriatic Sea. A probabilistic model is based on data calibrated using different satellite missions and wave model simulations. These data had been collected from 1992 up to the beginning of 2016, which means they are most recent. Likewise, the presented data are more appropriate for statistical analysis than the data collected by visual ship observation because the sampling interval is constant and no bias error is introduced like in the case of visual observations.

The results of this analysis show that sea states with significant wave heights lesser than $1 \mathrm{~m}$ are most frequent in the middle Adriatic Sea and they make almost $70 \%$ of all sea states. The average significant wave height reads $0.87 \mathrm{~m}$, while the absolute maximum significant wave height measured during 23 years is $6.05 \mathrm{~m}$, as recorded in December 1992.

The parabolic relationship between the wind speed measured at $10 \mathrm{~m}$ above the sea level and the wind-generated waves is established. The regression analysis shows that such a relationship is fairly reliable owing to its relatively high coefficient of determination.

The comparison with the Tabain's single-parameter wave spectrum shows that oneparameter spectrum is not sufficient to describe all relevant sea states in the Adriatic Sea and that it would be more appropriate to use two-parameter spectra. The spectral peak period of extreme sea states is slightly overestimated by the Tabain's wave spectrum.

The most probable extreme significant wave heights calculated in this paper are lower compared to the results obtained by previous analysis using wave buoy measurements in the north Adriatic Sea from 1978 to 1992.

\section{Acknowledgement}

This work has been fully supported by the Croatian Science Foundation under the Project 8658 . The World Waves data used in the study are provided by Fugro OCEANOR AS. 


\section{References}

1. M. Katalinić, M. Corak and J. Parunov, Analysis of wave heights and wind speeds in the Adriatic Sea, Maritime Technology and Engineering (2014), 1389-1394.

2. J. Parunov, M. Ćorak and M. Pensa, Wave height statistics for sea keeping assessment of ships in the Adriatic Sea, Ocean Engineering 38 (2011), 1323-1330.

3. Hydrographic Institute of Republic of Croatia, Atlas of the Climatology of the Adriatic Sea (1979).

4. L. Cavaleri, S. Curiotto, A. Mazzoldi and M. Pavanati, Long term directional wave recording in the Northern Adriatic Sea, Il nuovo cimento 20 (1997), 103-110.

5. T. Tabain, Standard Wind Wave Spectrum for the Adriatic Sea Revisited (1977 - 1997), Brodogradnja 45 (1997) 4, 303-313.

6. L. Cavaleri, The wind and wave atlas of the Mediterranean Sea- the calibration phase. Advances in Geosciences 2, (2005), 255-257.

7. S. Barstow et al., World Waves: Fusion of data from many sources in a user-friendly software package for timely calculation of wave statistics in global coastal waters, The Thirteenth International Offshore and Polar Engineering Conference. International Society of Offshore and Polar Engineers, 2003.

8. S. Barstow, Long-term World Waves data in the Adriatic Sea, Fugro OCEANOR, 2016. (internal communication)

9. D. Zec, L. Maglić and M. Šimić Hlača, Maritime Transport and Possible Accidents in the Adriatic Sea, 17th Annual Conference of the European Environment and Sustainable Development Advisory Councils EEAC 2009.

10. P. Queffeulou and A. Bentamy, Analysis of Wave Height Variability Using Altimeter Measurements: Application to the Mediterranean Sea, Journal of atmospheric and oceanic technology 24 (2007), 2078-2092.

11. J. Parunov, Methods for long-term prediction of extreme sea states, Brodogradnja 48 (2000) 2, 131-138 (in Croatian).

12. J. Parunov and I. Senjanović, Združena razdioba vjerojatnosti značajnih valnih visina i nultih valnih perioda, Radovi FSB XXIII (1999), 25-33 (in Croatian)

13. Det Norske Veritas, Recommended Practice Dnv-Rp-C205, Environmental Conditions and Environmental Loads, October 2010.

14. N. Leder, A. Smirčić and I. Vilibić, Extreme values of surface wave heights in the Northern Adriatic, Geofizika 15 (1998), 1-13. 
Andrea Farkas, Josko Parunov, Marko Katalinić

\title{
Statistika valova središnjeg dijela Jadranskog mora
}

\begin{abstract}
Sažetak
U radu su prikazani metodologija i rezultati statističke analize stanja mora srednjega Jadrana. Studija je temeljena na World Waves Atlasu koji sadrži podatke o stanjima mora u Jadranskom moru dobivene satelitskim mjerenjima i numeričkim simulacijama kroz protekle 23 godine. Na temelju podataka iz Atlasa, izvedene su tablica stanja mora i ruža valova za lokaciju u srednjem Jadranu. Također su određene teorijske dugoročne razdiobe značajnih valnih visina i vršnih spektralnih perioda. Koristeći regresijsku analizu, uspostavljena je veza između brzine vjetra i značajne valne visine. Vršni spektralni periodi su uspoređeni s Tabainovim spektrom valova koji se, uobičajeno, koristi za stanja mora u Jadranskom moru. Konačno, određene su najvjerojatnije ekstremne značajne valne visine za različite povratne periode te su rezultati uspoređeni s prethodnim istraživanjem dugoročnih prognoza stanja mora u Jadranskom moru.
\end{abstract}

Ključne riječi: Jadransko more, statistika valova, satelitska mjerenja. 
